\title{
NeW REQUiREMENTS FACING The Training OF ENGINEERS FOR ECONOMIC GOBALIZATION
}

\author{
Cus, F. \& Balic, J.
}

Abstract: Universities and colleges worldwide are the most important factor of globalization for filling the deficit of knowledge and improving the dialogue between people and cultures. In the social role they use their autonomy in discussions about outstanding ethical and scientific issues facing tomorrow's society. Targets of modern academic education stress high flexibility of curricula, mobility of students and teachers, introduction of a study and course credits system, integration into European research projects, etc. We must forget the idea of giving an engineer during their study all the knowledge they might need later on, particularly because engineering knowledge becomes obsolete in some technical spheres within a few years. Training of engineers in Slovenia is a common heritage, therefore at the present stage of development it cannot be left to market laws, since education is a basic human right and a universal human value.

Key words: economic globalization, education, engineer, Bologna processes
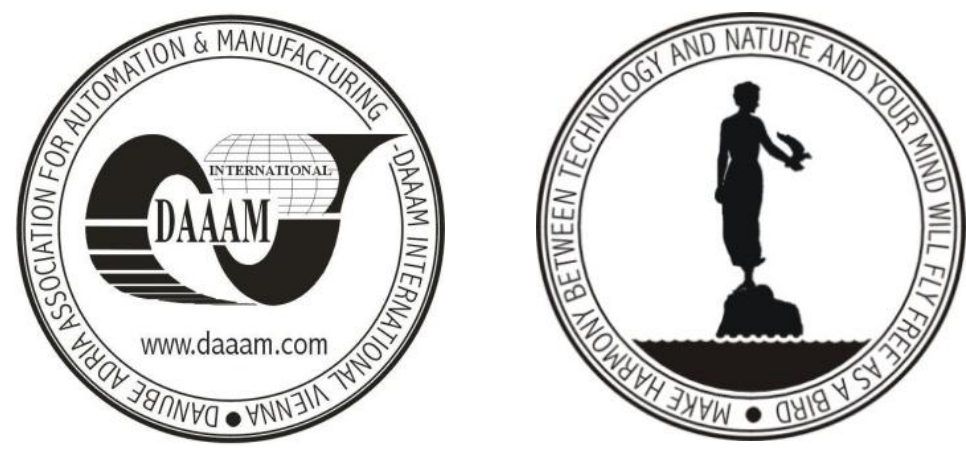

Authors' data: Cus, F[ranci]; Balic, J[oze], University of Maribor, Faculty of Mechanical Engineering, Slovenia, franc.cus@um.si, joze.balic@um.si

This Publication has to be referred as: Cus, F[ranc] \& Balic, J[oze] (2013) New Requirements Facing the Training of Engineers for Economic Globalization, Chapter 29 in DAAAM International Scientific Book 2013, pp. 545-560, B. Katalinic \& Z. Tekic (Eds.), Published by DAAAM International, ISBN 978-3-901509-94-0, ISSN 1726-9687, Vienna, Austria

DOI: 10.2507/daaam.scibook.2013.29 


\section{Introduction}

Employment structures change in correlation with the social progress and the fact that machines are replacing humans; the number of manual workers drops, while the functions of control, management and organization are multiplying, which results in strengthening the need for mental capacities of employees at all levels. In industrialized countries scarcely even a quarter of employees actually work in industry. The transition from the industrial into the service society is in full progress and is taking place at full speed. Radical structural changes are taking place in technology, economy and society.

Those structural changes are characterized by:

- complexity of technical and economic processes

- internationalization and globalization of production and markets,

- strengthening of competition due to relocating research and production into cheaper environments,

- ambivalent attitude of society towards technology and ambivalence of technology itself.

Is the Engineer of tomorrow only a technician? New traits of structural changes impose new activities on employees because of accelerated innovation burdened with higher-quality and cheaper production and improved offer of services. This is enabled by reorganization of hitherto management structures and work in companies. This trend is oriented away from the horizontal and vertical stable structure to open, flexible and user friendly organization systems. The hierarchy is reduced, the decision competences are taken to the operational level and the work areas are professionally and functionally interconnected.

\section{Employers Understand Quality as the Knowledge and Skills of Graduates}

However, the quality of training has a completely different meaning for students. In their opinion quality is to be focused on industrial development and preparation to reach a certain position in the society.

Changed orientation in companies' work and decision processes also impose changes on engineers because of training profiles and their employability [2]. As a consequence of those structural changes other skills apart from professional capacities are required from engineers:

- team work (skill and readiness for interdisciplinary cooperation in work an decision-making teams),

- methodological competences (skill and readiness for systematic and connected thinking and action),

- social competences (integration of social, political, economic, ecological and ethical dimensions of engineering planning and acting in the development and implementation of techniques) and language competences, mobility and 
flexibility (capacity of living in internationally structured professional and work environment).

All this imposes the need for radical changes of education structure, selection of study contents and learning methods as required by the Bologna reforms of the existing education system. Education, formal and informal, must serve the society as a tool for strengthening creativity, development and expansion of know-how and science; knowledge and teaching must be accessible to all.

In Slovenia attention must be paid in order to avoid 'politicisation' of the educational and cultural values and a drop in the government's interest in economic modernisation.[1] If that should happen, the universities and colleges would become merely a tool of the political struggle and appendix of the government apparatus.

\section{Economic Globalization has Set In}

As the globalization process is ever nearer to the entire population of the planet without restraint, the awareness increased that "my neighbour may not be similar to me". Many people might be alarmed by that fact, since it ruins the stable traditional idea of neighbourhood, community and nation, devastates the strongly established ways of relations between human beings and makes ethical diversity something commonplace.

On the one hand, economic globalization links the producers and consumers of different continents and areas into a functional relation. Today's world economic companies are organized in such a way that a single product can contain components made in a dozen factories in as many countries. The managers and employees in those companies often spend more time cruising between these countries than on leisure in the company of family and friends like the adventurous seekers of happiness in the past. It would be erroneous to claim that the present restructuring of the world economic relations does not affect the personal views and values of all those involved from the unskilled worker at the assembly-line in a poor country to the user of a product whose label indicates that it has been made in a remote country. On the other hand, the rapid growth of communication networks, particularly the audiovisual media, brings into the homes of millions of people what was previously a set of unconnected events from remote places, from metropolitan neighbourhoods to city slums and remote villages, like, for example, the Asian " tsunami".

Though the former industrial economies are in fact in the process of deindustrialization and are transferring a great deal of production capacities into foreign countries, mass immigration of culturally different people from other countries exerts an increasing pressure on traditional labour markets and on the social tissue of the host countries. Slovenia must accept those processes and must be aware that it is caught in the wave of globalization too.

\section{Drawbacks of the Present Training of Engineers}

Today at the faculties of mechanical engineering a great number of young people are preparing themselves either for the scientific work or for specialized 
employment. Faculties must continue to be the source quenching the thirst of knowledge of more and more people regarding in their curiosity of mind the sense of their existence. In Germany the following problem areas have been spotted in the implementation framework of engineering study reforms :

- students lack information about the study process, the system of universities and colleges, communication and behaviour in scientific activities of universities,

- overstressed isolated factual knowledge to the detriment of skills and exercises of methods of learning and work, problem solving, and presentations,

- strong professional egoism of teachers and lack of coordination of study contents in study programs,

- tight deadlines imposed on students in terms of required tasks, group activities or work duties. lack of communication between all participants of the scientific environment about targets, contents and organization of studies.

Such problem areas are also present in our university education system. Fortunately, having thoroughly analysed the situation in the country, we are attempting to reform the existing system into a system comparable to Europe and compatible with nearby universities. Many experts point out that university reforms are viewed with mistrust. In this area almost all attempts have been made, but the results only rarely meet the expectations. It seems that in many countries numerous consecutive and contradictory attempts of reforms only increased the resistance of university systems to changes. Nevertheless, the changes in European countries are gradually continuing in the direction of the Bologna processes, somewhere faster and elsewhere more slowly[3],[4].

\section{New Requirements for University Education}

Any engineering activity needs a combination of theory and practice in proper ratio. While in research the theoretic abstract handling of set problems is in the foreground, the accent in production, assembly, maintenance, technical sale and service is more on the practical concrete domain. Talent, inclinations, capacities and skills are expressed in similar ways differently.

The university system must consider professional practice as well as the element of students' talent. For economic success it is very important that all positions in innovation process are occupied by competent and motivated engineers. The requirements of the degree of education must be extended to education profiles. Experience shows that different degrees of education are hardly feasible in the unified form of university or faculty. Therefore, overall equal-right but different handling of education is needed in higher technical and university programs.

The differentiated system of engineering education in Slovenia with different degrees inside the faculties meets these requirements and works with all advantages and disadvantages. However, it is most important that the students finishing both forms of education find jobs in their field, appropriate for their degree of education 
[6]. However, the economic and technological achievements will lose their true importance if the humanistic and cultural traits do not become the central ingredient and target of development attempts. In the $21^{\text {st }}$ century, when the industries are oriented more towards technology and the human society towards knowledge, the human capital, as developed with the assistance of education and training, will take on an increasingly important role.

\section{What are the New Contents Requirements of Engineering Education?}

Engineering comprises different activities and workplace characteristics . It depends on various factors, such as the professional sphere, the employer, company size and other factors requiring specific knowledge and skills of employees. This variety must be covered by engineers' basic education [7],[8],[9]. The basis of engineering education is the spectrum of mathematical-scientific and technical bases. That basic knowledge is key to understanding natural phenomena and to applying their principles in technology. They represent the foundation for the superstructure of the deepened knowledge in the individual areas of application. A large extent of bases would preferably allow professional communication with engineers and scientists from other fields. Interdisciplinary and non-technical contents receive additional importance. Those contents complement and complete the professional education of engineers facing complex tasks for which the technical knowledge and capacities are not sufficient.

In that way engineers reach their market value in the professional activities. $\mathrm{He}$ is capable of solving problems and managing projects creatively, of behaving cooperatively and highly socially with managing and communication competences so that responsible, humane and environment friendly behaviour is encouraged. However, the mere mastering of the bases of engineering does not yet bring professional success. To cope with the requirements of professional practice engineers must deepen their knowledge in a certain technical sphere and need special knowledge of problem solving methods. Due to the increased complexity of modern devices and systems overall, it is required to have insight, systematic thinking and the capacity to communicate at system level with all project participants . The engineers are expected to cope with increased requirements to understand the theory because of increasing complexity of design, manufacture and sale of technical systems and processes.

The association of German engineers (VDI - Verein Deutscher Ingenieure) recommends further development of the existing structures of engineering training. Roughly, they recommend the following structure of engineering education: $30 \%$ mathematical-scientific, $30 \%$ technical, and $20 \%$ interdisciplinary contents, and another $20 \%$ deepened professional knowledge. The basic knowledge is the foundation for the required future professional mobility of engineers. However, the renovation and any proper reform of university education must be a result of deep and deliberate judgement and understanding of special circumstances and requirements important for any special situation. Relevant decisions must be made in 
common agreement by providing proper answers between all participating sides in the framework of the medium-term process of changing university training.

\section{Which Crucial Requirements Does an Engineer Face Today?}

It goes without saying that engineers must be extremely qualified to master their narrow professional sphere [9],[10],[11]. Across that sphere it is crucial that they are able to work in teams. Their thinking must be logical so that they are able to handle and incorporate in their work the interdisciplinary topics from environmental protection and economy which are on the edge of the narrow specialization. They must understand the assumption of "globalization", which is important for the growth of the company, they must learn foreign languages and be ready to work abroad.

At the management level engineers must be ready to take risk, they must permanently ask themselves different questions, promote materialization of new ideas, be familiar in time with the dynamics and instability of new technologies and provide overall solutions with the capacity of clear public justification, and have the capacity of communicating with experts and non-experts, since the dialogue with society is more and more emphasized. All the above mentioned demands and properties cannot be acquired during their studies, which are becoming shorter and shorter. To that end, additional training is necessary as a complement to the university study. In spite of that the university programs will have to be adapted to the "soft factors". It is estimated that in the future more and more people with computer knowledge will be available. The companies whose power will be outside the computer spheres will be preferred: the power to eliminate conflicting matters, cultivate mutual relations within the company and with other companies, enhance personal responsibility of the employees, collaboration and increase of trust between superiors and employees, maintain maximum motivation, integrate employees into the decision-making process in order to meet the company's targets and allow participation in success. All that will be incorporated into the study courses of the future. In addition to their technical competences, engineers will also master the "soft factors". To train and qualify such "globally thinking and creative engineers" is an important competitive task of faculties of mechanical engineering.

Engineers of the future will not be only "technicians", they will be responsible for the "whole". This is a challenge for young people wanting to help to organize our world. The work of an engineer is an interesting, tense and responsible task.

\section{Engineers Promote Technological Changes}

The society consumes what the engineers have produced. Only a few engineers follow exclusively their ideals and imagination. Most engineers have some target which is incorporated in the society whose needs they satisfy by manufacturing products to serve people.

Engineers with greater innovativeness promote technological changes. Sometimes these are hardly traceable changes, the next time the idea born causes abrupt changes. Who changes technologies? The answer is: the society receiving 
engineers' results. If the society were satisfied with what it had, engineers would be unemployed. Engineers should have control over technical sciences; they should recognize if a new product is good or bad for people and their environment. Do engineers always act in that sense and eliminate the novelties which might do harm?

Today, engineers face the objection that they cope with the market pressures by turning a blind eye. The one they turn blind is the one that that should pay attention to the environment and ecology.

So, today we are at the stage of changes when our society imposes accelerated development in two directions. Both should be done by the engineers. The consumer follows the path of novelties hoping to gain better facilities, more comfort, and pleasure.

Thus we vividly jump from novelty to novelty and more and more loudly and audaciously call for the next "trick" of the technical blessing. The first direction requires technical development, while the second direction establishes that someone has to dispose of the waste. To follow both directions engineers are needed who meet the market needs and cause as little waste as possible [12].

Up to what speed of technological changes will it be possible to define the profile of an engineer who could meet the different demands of our society? What base of knowledge and capacity must an engineer have to be able to choose the way leading into the future?

\section{Engineer Should Follow Interdisciplinarity}

The profile and spectrum of an engineer's activity cannot be like decades ago, since today our life is marked by three crucial changes:

- Our society relies completely on technology. Without technology today's mankind would hardly survive.

- Technical development has made such advances that the advancements in technology can no more be supervised. The world is flooded with technical information which cannot be unequivocally evaluated any more.

- Today, it is already clear to us that our handling of technology will ruin the base of our existence, our environment.

Therefore, it would be misfortunate if future engineers were to lead us to rapid technological changes, even though they were the pioneers who technically shaped the society. The present time requires another profile of engineers.

Primarily, engineers must be able to generalize. Mastering an individual technique up to the smallest detail is not useful, and may even be dangerous, if it is not linked with related techniques. Independent technologies do not exist! To be able to permanently recognize the crucial contact points in today's flood of information, engineers must acquire a solid basis for comparison. That basis consists of the wide basic knowledge and general education.

Engineer have the role of pioneers. They must foresee, consider the past and provide covering; in a word, they must be mindful. That also means that they must 
not carelessly or even euphorically grasp any attractive technical novelty appearing on the horizon. They must know who will follow them, since among their followers are not just people who not know much about technology, but also thinking humanists and financially strong contemporaries. Therefore, engineers must be able to lead.

Engineers must recognize technologies useful or harmful to humanity. They must be constantly aware of the consequences of their doings.tThey must not allow anything or anybody to turn them away from the development path they were botn to. Technology is not a sphere of knowing, remaining in the head, it is not philosophy. The target of technology is always practical application.

Engineers must be brisk enough to be able to follow technological changes. If they are too slow, the society escapes them with random technologies.

To be quick and mobile, engineers must not carry heavy ballast. Erudition without true knowledge, prejudices or science not connected with the basic knowledge can only be an obstacle.

The centre of engineers' work must not be one-sided picking-up of knowledge, since their activity must be primarily intended for the responsible transfer of his knowledge into practical application. In this sense engineers are different from theoretical scientists. If engineers restrict themselves to mere acquiring of knowledge, they may soon end up as a technical archivist hardly contributing to technological changes.

Engineers must be capable to get an idea of hierarchy of problems in the context. It is not sufficient that they only recognize the technological context. It also means: engineers' thinking must be system-based, so that they can classify what is in the foreground, with respect to its importance.

Engineers must have team work skills not to get lost on the wrong path. Due to the extent of today's technological events the time of the so-called "engineershermits" has gone.

Engineer must address the problem. They must not be opportunists and take the easy way out, even if no one is looking but instead assume their responsibility towards the society.

Engineers must be time-conscious. Work-shy and less burdened engineers often do not pay attention to enough in detail and do not finish in time.

Though technology develops rapidly, engineers must rest at least with one foot on the ground. Engineers who have left the ground of reality often do not land where our society needs them.

Engineers must have enough courage to reject a new technique and revive an old one, if that is better for the human society. Engineers must never support the blind belief that the newer technique is always the best. The time-neutral flexibility of thinking will be more and more important in the coming years.

In the future engineers will have to be more ready to solve problems with the simplest tool. They must never rely on the idea that the newest technology is always available. Still, they should always know how to light a fire if electricity fails! 
Engineers must work methodically and systematically, they must not rely on their instincts. However, it is also wrong, if engineers use methods and procedures thoughtlessly and without feelings.

Engineers must never adopt "finalism". They must always take into account that other engineers, too, will work on the same matter . They also should not invent technologies bringing hardly solvable problems of waste matter disposal.

Engineers must believe in the future. They must not show unjustified optimism and create unrealistic atmosphere of technical feasibility.

The sooner the technology changes, the farther into the future the responsible engineer's thinking must reach. At present speed of development we are making progress with quick steps and where will the micro-,information, bio- and other technologies take us to?

Intercepting the accelerated technological development in the whole sphere of technology, engineers will become more important.

Engineers will be able to do that in the future if they form their professional identity continuous professional development [14]. Complementary education and post-graduate studies must become an integral part of engineers' lives!

\section{Organization of Study According to the Bologna Processes}

The hitherto form of the undergraduate study in Slovenia was changed with the new law on university education [13]. The Bologna processes impose reforming of engineering professions according to the formula $3+2+3$.

Undergraduate studies will last three years and master studies will last two years. The Slovene government has confirmed that students can now enrol in programs which have switched to that type of study. The faculties' responsibility is to organize studies that will enable students to finish successfully within the prescribed period. The studies must motivate students for success and have great importance in obtaining proper education. Of course, there are many internal university, social and personal obstacles often prolonging the study period.

Special motives are necessary for engineering professions. Some students recognize them in time and successfully fulfil all study obligations. Regrettably, there are many students who "try to find themselves in the engineering profession" and find out after a certain period that this is not their future, and then switch to other studies.

The Faculties are introducing the tutor-system studies, where the students can freely cooperate with the tutor who helps them on their study path during the year. Regrettably, experience shows that students do not cooperate actively enough.

In order to adhere to the targets of the Bologna declaration it is primarily necessary in Europe to reform the existing curriculum to shorten the studies. It is well known that university education cannot avoid the constraint and necessity with which the need for university reforms is introduced at the political level in order to meet all the requirements of the economy. Actually the national system of university education has become so differentiated and complicated (with respect to structures, programs, students and financing) that it is hard to discern the clearly separated 
categories. In the changed circumstances some faculties will have organizational, financial and personnel difficulties for introduction of Bologna education processes [14]. Renovation and any proper reform of the university education must be the result of deep and deliberate judgment and understanding of special circumstances and requirements important for any special situation. That must be decided by consensus by means of proper agreements between all participants in program implementation .

\section{University Education and Changeable Market}

Over the last decade, university education in a major part of Europe was in a crisis. Structural adaptations and political changes affected the income of universities and colleges. With unemployment of graduates and brain drain the trust in university education has been shaken. Excessive enrolment in social sciences has led to unbalanced relation between groups of graduates entering the labour market. As a result, graduates as well the employers are disappointed - particularly with the knowledge quality offered by universities.

Also in Slovenia the increase in the number of the enrolled students and the number of institutions affected the growth of expenses for university education; the latter faces, of course, the extraordinary difficulties with mass enrolment [15]. For a long time, there has been no mass enrolment in engineering professions. Lately, renewed interest and absence of the tendency towards enrolment dropping can be noticed. If Slovenia wants university education to be one of the principal driving forces of economic development and at the same time a guardian and generator of knowledge, then concrete action will be necessary when switching to the Bologna model of study. Such action includes particularly investments into research, since it is very important that universities retain the research potential in their areas of competence. On the other hand, only these institutions have a position allowing them to fulfil their traditional role necessary for scientific progress. That position is guaranteed by their intellectual freedom, freedom of discussion and independent evaluation of achievements.

Research activity in social as well as in natural sciences must, of course, be independent from political and ideological pressures, but it must contribute to the long-term development of society. Scientific research must avoid the traps of the narrow-minded academic approach and hermetic thinking, particularly in an environment where the need for technological progress is especially high. On the other hand, the quality of science must not be sacrificed in favour of immediate productivity, since science is a universal and long-term value.

\section{Role of Scientific and Technological Knowledge in Society}

If the economic trends in Slovenia are oriented towards high technologies, faculties will be compelled to intensify scientific and technological training in answer to the requirement for experts who would be familiar with with cutting edge technologies and be capable of controlling ever more complex systems. 
Since at present there is no reason for the supposition that trends will change, faculties must continue satisfying the requirements and continue adapting specialized study courses to social needs. That task is difficult and must not be underestimated. Division of knowledge by separate sciences does not always meet the market needs and the institutions with best achievements are those which have developed flexible and cooperative forms of teaching without boundaries between sciences. Training of engineers in Slovenia is a common heritage, therefore at the present stage of development it cannot be left to market laws, since education is a basic human right and a universal human value.

Today, many scientific universities in Europe face the problem of whether the best students should be pointed in the direction of research or industry [15],[16]. Slovenia must try to impose flexibility of the education system to retain ample university education in order to suitably prepare engineering graduates to enter the labour market. That dimension must be retained at the Faculty of Mechanical Engineering. In the future, our region will still structural change and the latest information shows that the demand for mechanical engineers is on the increase again. This represents new challenges for the Slovene faculties of mechanical engineering in forming curricula in accordance with the Bologna processes. One of the main objectives of the education reform of mechanical engineers and probably the best way to implement it is involving all stakeholders into the decision making process. . Triple target: equal rights, adequacy, and excellence must be considered. Searching for coordinated linking of those targets is the key responsibility of those participating in planning and implementing the Bologna process in training of engineers.

\section{What Can Education do for Engineers?}

What is essential in the technical education can be justified only with autonomous thinking processes. If only traditional knowledge is offered, what is essential for the future only rarely breaks through into the foreground. Interpretation of knowledge is desirable. In training of engineers we must continue to support effectiveness.

Wide general and basic education must strengthen technological mobility. This will build a more solid basis for the interdisciplinary activity and for intercepting new technologies. The prerequisite for interdisciplinary activity is the capacity to work in team. The engineers must acquire the capacity for team work already in the time of training by group and joint work. However, the engineers must be capable to act independently any time, but they must not be brought up as solitary wolves.

We must abandon the idea that we will educate "ready-made" engineers. Much of what was imparted in undergraduate education must find its place in complementary education. As the applied knowledge soon becomes obsolete, if must be quickly replaced. More than ever today's undergraduate education must concentrate on the best possible concepts for later complimentary education.

Undergraduate education Primarily must allow mastering of processes leading to solutions applicable in practice. It must not be limited to general bases.Technical applications resting on natural laws can be interpreted and selected. That fact is more 
and more important in the accelerated technical development. Education may have ready conventional answers, but it should no longer present ideal formulas which would be binding, since they risk missing what is essential.

It may be concluded that education helps the engineer to form his profile, but it can also hinder it. Attempts to convey the profile often fail - although they are introduced by prolongation of the study period, since the changes in today's technologies are underestimated and engineers, able to act, are not equal to storages of knowledge in practice. Education may accompany the engineer who will only become engineer. As companions we must not forget that we are accompanying someone who walks alone. He should not be pulled or pushed, but only accompanied - we should give him what the needs on his path and not more. The companion must also know that he, who will tear himself away from him, will have to find his path independently. The companion has other tasks. He must lead other passers-by to the profession of the engineer past the reefs.

Our civilization, relying on technology, will survive only, if our society is populated by more people i.e. engineers who know the technology well. In case of lack of engineers accelerated technological changes will not lead to solutions our environment urgently needs.

Therefore Slovene university and college education is called for to take part in that social responsibility and offer study programs in accordance with the new development paradigm. Today's range of curricula in Slovenia and at German universities and colleges is too specialized, broken and remote from reality from the point of view of the observers from industry [16],[17]. Therefore engineering education in Germany is an important topic of reforms, which with the new law passes into internationalization.

Though their engineers are already renowned worldwide today, the German curricula lack attractiveness to foreign students. Whoever wants to be successful in the global world of education will have to adapt to the market demand. Today, most orientations of the Anglo-Saxon model, which is internationally compatible and features the degrees "Bachelor", "Master" and "Ph. D.", are wanted; they are also envisaged by our law. German economy compels universities into accelerated reforms in order to increase the demand of students from East Asia [18]. These represent their future clients, collaborators and/or "ambassadors" of medium-sized enterprises.

Slovenia should learn much from such thinking! Slovenia has adopted the relevant laws on universities [19]. That is a unique opportunity to quickly correct the flaws in our university education. Unfortunately, this has not been done so far and we will be forced again to adopt quick and incomplete solutions.

\section{Quality as Change}

This attitude is concentrated on the participants in education, on their acquisition of new skills and knowledge. Looking at different definitions of quality we can see that there is no correct or uniform definition. Quality, thus, is not an unequivocal and uniform term, it is rather defined in terms of more than one kind of quality. It is 
necessary to consider a series of different interest groups having different starting points, values and expectations and, consequently, different ideas of the purpose and targets of university education. Therefore, there are different ideas of what quality in university education is [20].

In the opinion of experts for evaluations of the university education quality is a relative and multidimensional concept. Verification of quality is relative with regard to various targets the university education has or measuring it is relative with regard to different aims of different participants. In university education there are many interest groups with different requirements concerning quality of university education. Therefore, we cannot speak of one, but of more qualities. In university education there are as many definitions of quality as there are interest groups. It is necessary to distinguish the quality requirements expected by e.g. students, academic personnel, employers or government. For the government the quality of education implies that the students finish their study at reduced costs within the prescribed time with a diploma of international standard [21].Employers understand quality as graduates' knowledge and skills. To the contrary, in the opinion of students, quality is associated with individual development and with preparation to reach a certain position in the society. Education must be associated with students' personal interests. However, the education process must be organized in such a way that students can finish their studies within the prescribed time. Academic circles will define the quality as academic qualification based on satisfactory transfer of knowledge, satisfactory study environment and proper combination of researches with teaching [22].

Different interest groups conceive quality differently. Thus, quality is relative and its definition depends on the interest group. However, even within those groups there are sub-groups defending separate interests. The complicated question can be solved by considering the criteria of different groups and their judgement of quality rather than by a single definition of quality. Such solution allows and admits the right of different groups to their different perspectives. Due to different concepts of quality of university education the final answer will probably never be reached. There is no ideal system of quality verification and assurance acceptable for all sides.. The balance between these concepts will always be unstable.

External evaluation of university or college institutions covers:

- strategy, organization and management of institutions, record keeping and quality management,

- education - study activities,

- scientific - research, artistic and professional activity,

- university teachers and workers, scientific workers and collaborators,

- administrative and professional - technical workers,

- students at the institution,

- rooms, facilities for educational and scientific research, library,

- financing of educational/study and scientific research and professional activities, 
- cooperation with the social environment at the regional, national and international level.

For evaluation of cooperation with the social environment at the regional, national and international level the following criteria are applied:

- University has established successful cooperation at the regional, national and international level. It promotes cooperation with other university institutions, companies, organizations and professional associations and with other important interested participants in the environment.

- University features integration of all those interested into its activities in the educational, scientific-research or professional areas.

- Curricula and other educational activities of university reflect the needs of economy and noneconomic activities; it cooperates in planning and monitoring the educational activity of the university.

- Scientific research and professional work of the university are associated with development projects and researches for economy and non-economic activities.

- University takes part in the exchange of students, teachers and collaborators, scientific workers and collaborators within Slovenia and abroad.

\section{Conclusion}

Faculties of mechanical engineering also must carry out differentiation and orientation of curricula efficacy so that they can be a generator of economic development [23]. We are aware that the structure and extent of responsibility of the faculty are influenced by the changes in the political, social, economic and technological environment of the faculty. We must forget the idea of giving engineers during their study all the knowledge they might need later on, particularly because engineering knowledge becomes obsolete in some technical spheres within a few years.

Targets of modern academic education stress high flexibility of curricula, mobility of students and teachers, introduction of crediting system of study and/or set of courses, integration into European research projects, etc. Competition forces faculties of mechanical engineering into a struggle for students where they apply marketing strategies, to improve in program planning, offering study advice, and promoting their services. . To increase attractiveness and scientific prominence it is necessary to determine the value of graduates on the labour market, quality of tutors and lecturers, quality of student life, values and mission. Today faculties of mechanical engineering are traditionally scientific faculties, where basic research is predominant: free selection of the type of research, orientation towards future, multidisciplinary approach. The target is top European quality. Support is necessary at all levels for numerous projects of cooperation between university and economy, including teachers and students and bringing a series of educational advantages. 


\section{References}

Albers, A., Matthiesen, S., Neue Modelle für die Ingenieurausbildung. Das Karlsruhe Lehrmodell, (New models for engineering education. The Karlsruhe teaching model) ASEE - The American Society for Engineering Education, http://www.asee.org/papers-and-publications, http://www.asee.org/conferences-andevents/conferences

$\breve{C} U \breve{S}$, Franc, Analysis of monitoring quality in Slovenian higher education area. 29th International Conference on Organizational Science Development, 24-26 March 2010, Portorož , Slovenia : proceedings

ČUŠ, Franc, BALIČ, Jože. Bases of changes of university education and education tasks of University of Maribor for global society. XVIII skup Trendovi razvoja "Internacionalizacija univerziteta ", Trend 2012, Kopaonik, 27.02-01.03. 2012, zbornik radova (proceedings), Novi Sad, 2012, str. 13-16

ČUŠ, Franc, BALIČ, Jože. QA system in Slovenia and quality assurance practices on the University of Maribor. XV skup Trendovi razvoja, Trend 2009, (collection Development Trends) Kopaonik, 02-05. 03. 2009, zbornik radova, (Proceedings). Novi Sad, 2009, str. 110-115

ČUŠ, Franc, BALIČ, Jože. The Bologna process beyond its initial deadline in 2010 Bologna - What's next?. XVII skup Trendovi razvoja (collection Development Trends) "Evropa 2020: Društvo zasnovano na znanju",( Knowledge-based society) Trend 2011,Kopaonik, 07-10.03.2011.Zbornik radova (Proceedings).2011, str. 22-25. ČUŠ, Franc, BALIČ, Jože. The Bologna process beyond its initial deadline in 2010 Bologna - What's next?. XVII skup Trendovi razvoja (collection Development Trends) "Evropa 2020: Društvo zasnovano na znanju",(Knowledge-based society) Trend 2011,Kopaonik, 07-10.03.2011. Zbornik radova (Proceedings).2011,str. 22-25. ČUŠ, Franc, KOPAČ, Janez. Vzpostavljanje sistema zagotavljanja kakovosti pri izobraževanju inženirjev32. posvetovanje Orodjarstvo in strojegradnja 2010, Ljubljana, 6.-7. Oktober 2010. zbornik posvetovanja. Ljubljana: GZS, Združenje, 2010, str. 73-79, (Establishing a system of quality assurance in education inženirjev32. consultation Tool and Machine 2010 Ljubljana, 6th-7th October,2010. conference proceedings. Ljubljana: Chamber of Commerce Association, 2010

Die Zukunft exzellenter Ingenieurausbildung (The Future excellent engineering education ) „Next Generation Engineering Education“ (8.6.2011)

Februar 2005, www.vdi.de/nc/ueber-uns/vdi-vor.../ak-e-m/? ... pdf

http://www.digbib.ubka.uni-karlsruhe.de pdf

http://www.sbfi.admin.ch/dokumentation/.../index.html? pdf

Ingenieurausbildung in der Schweiz, INGCH setzt auf FH- und ETH-Ingenieurinnen und Ingenieure (Engineering education in Switzerland, INGCH relies on FH and ETH engineers) http://www.ingch.ch/pdfs/m_17.03.2010.pdf

Käfer Gerhard, Ingenieurausbildung in Österreich, e \& i Elektrotechnik und Informationstechnik, (Engineering education in Austria, E \& I Electrical and Computer Engineering), November 2006, Volume 123, Issue 11, pp 493-494

Kiener, U., Zukunft Engineering, Eine Expertenbefragung in der Schweiz im Auftrag des ETH-Rates und des Bundesamtes für Berufsbildung und Technologie, Winterthur 
2005, (Future Engineering, a survey of experts in Switzerland on behalf of the ETH Board and the Federal Office for Professional Education and Technology)

Kurzfassung der Thesen und Empfehlungen zur universitären Ingenieurausbildung. Diskussionspapier für das Präsidium der DFG, erarbeitet unter der Federführung von Vizepräsident Eigenberger, (Discussion paper for the Bureau of the DFG, prepared under the auspices of Vice President Berger own)

Molzahn, M., Bachelor \& Master oder Diplomingenieur ? Ingenieurausbildung im Wandel, Vortrag bei der Qualität der Ingenieurausbildung sichern und weiterentwickeln, (Bachelor \& Master or Diploma Engineering? Engineering Education in Transition, Presentation at the Safeguard and develop the quality of engineering education)

Qualität der Ingenieurausbildung. Betrachtungen aus Industriesicht. Sonderdruck aus Arbeitmarkt Elektrotechnik Informationstechnik (Quality of engineering education. Views from industrial point of view. Reprint from the labor market Electrical Information Technology)

www.zvei.org/.../Qualitaet\%20der\%20Ingenierausbildun ...pdf

SEFI - La Société Européenne pour la Formation des Ingénieurs - The European Society for Engineering Education, The European Journal of Engineering Education published by Taylor and Francis is the official journal of SEFI, http://www.sefi.be/ VDE -Empfehlung zur Ingenieurausbildung mit gestuften Hochschulabschlüssen, (Recommendation for Engineering Education stepped university degrees) http://www.vde.com/de/Karriere/Ingenieurausbildung/Documents/Empfehlunggestuft eIngAusb2.pdf

VDI NACHRICHTEN, Berufsprofile, Funktionsbereich (Professional profiles, functional area) "Engineering im Anlagenbau" Montag, 1. Juli 2013, http://www.ingenieurkarriere.de/

VDI, Neue Wege in der Ingenieurausbildung, Gründung des „David-Gilly-Instituts für Lehre, Forschung und Kommunikation im Bauwesen" (New approaches in engineering education, founding the "David Gilly Institute for Teaching, Research and Communication in Construction) in Cottbus, www.vdi.de/nc/bildung/.../3.../weitere-poster/? pdf

VDI-Arbeitsgruppe Engineering \& Management im VDI Bezirksverein NordbadenPfalz Mannheim, 15, (VDI Working Group Engineering \& Management Association Northern District of VDI Mannheim Baden-Palatinate, 15)

Werde Ingenieur "Made in Germany", Die TU9, eine Allianz der führenden Technischen Universitäten in Deutschland, wirbt weltweit um talentierte (Become an engineer "Made in Germany", The TU9, an alliance of the leading technical universities in Germany advertises worldwide for talented)

https://www.study-in.de/de/--22241

www.dfg.de/.../universitaere_ingenieurausbildung_kurz....pdf

www.dfg.de/.../universitaere_ingenieurausbildung_kurz.... pdf

www.dvt-net.de/.../Qualitaet_der_Ingenieurausbildung.p ...pdf 